Reviews in Digital Humanities • Vol. 3, No. 2

\title{
Review: Undisciplining the Victorian Classroom
}

Roopika Risam ${ }^{1}$

${ }^{1}$ Salem State University

Published on: Feb 14, 2022

DOI: $10.21428 / 3 e 88 f 64 f .839 c 2179$

License: Creative Commons Attribution 4.0 International License (CC-BY 4.0). 


\section{Project}

Undisciplining the Victorian Classroom

\section{Project Director}

Pearl Chaozon Bauer, Notre Dame de Namur University

Ryan D. Fong, Kalamazoo College

Sophia Hsu, Lehman College, CUNY

Adrian S. Wisnicki, University of Nebraska-Lincoln

\section{Project URL}

https://undiscipliningvc.org

\section{Project Reviewer}

Roopika Risam, Salem State University

\section{Project Overview}

\section{Pearl Chaozon Bauer, Ryan D. Fong, Sophia Hsu, and Adrian S. Wisnicki}

Undisciplining the Victorian Classroom (UVC) is an open-access digital humanities project that reimagines how to teach Victorian studies through a positive, raceconscious lens. The project fosters the application of innovative, interdisciplinary teaching approaches by introducing less-studied, global, Victorian-era writers, artists, and communities into the classroom. Founded in the crucible of 2020 as a collaboration among four Victorianist scholars from different kinds of institutions across the United States, $\underline{1}$ UVC is committed to working in solidarity with the Black Lives Matter movement and national and global initiatives to challenge racist and xenophobic violence. Given this commitment to anti-racism and coalition-building, the project developers make every effort to reach consensus through a collaborative model of community based on care. This model aims to place the needs of our most vulnerable students and colleagues at the core of our work, while simultaneously honoring the knowledge and expertise of scholars of color, of scholars who share our critical priorities, and of fields that have grappled with race as a central concern. Thus, we understand our project as extending forms of radical care to: 1) the field of Victorian studies, a field that has been historically hostile to new knowledges and scholars of color; 2) our students, who demand more diverse content and methodologies; and 3) each other and our contributors, as collaborators at various stages of our careers. 
Our project builds on the interventions made by Ronjaunee Chatterjee, Alicia Mireles Christoff, and Amy R. Wong's essay "Undisciplining Victorian Studies," $\underline{2}$ which itself builds on Christina Sharpe's call for scholars to "become undisciplined" in undoing the racist epistemologies that they have inherited, unknowingly or not, from their predecessors. $\underline{3}$ As scholars initially trained in a national literature (Victorian literature) that has been integral to producing fantasies of white British superiority, we advocate for engaging scholarship in a number of areas to break disciplinary divides and inspire new modes of anti-racist teaching in Victorian studies. These fields include Black, African, Indigenous, Native American, Asian, Asian American, Latinx, postcolonial, decolonial, feminist, queer, transgender, disability, and critical ethnic studies. Victorianists can learn from the longer histories of these fields by taking up questions of race in robust ways and applying insights from these fields in making anti-racist teaching and scholarship a priority.

In conjunction with these new theoretical foundations, we developed our digital humanities project and corresponding website (now released in a formal first edition) through a process of careful and reflective collaboration while also heeding Bethany Nowviskie's call to organize ourselves "in deep empathy and interconnection with other fields and disciplines across multiple, varied scales." $\underline{4}$ In this vein, not only are we engaged in developing content and pedagogical approaches that incorporate the insights of the foregoing fields, but we also seek to promote the work of BIPOC/BAME scholars, early-career scholars, and contingent faculty-all of whom are structurally vulnerable and require specific forms of care as they confront the effects of neoliberalism on higher education.

This commitment to equity further informs the technical design of our site, which incorporates features to support accessibility for multiple audiences, including people with disabilities. From its conceptual underpinnings to its coding, Undisciplining the Victorian Classroom models radically collaborative forms of pedagogical praxis that can help create a more just and anti-racist future for our field and the academy more broadly. In doing so, the developers believe that Victorian studies and academia writ large can start to become the equitable, anti-racist space we imagine it to be.

\section{Project Review}

\section{Roopika Risam}




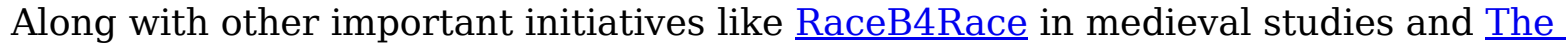
Bigger 6 Collective in Romanticism, Undisciplining the Victorian Classroom (UVC) examines how to move Victorian studies beyond its canonical moorings to address race in Great Britain and the British Empire. While other initiatives have focused primarily on research, UVC offers an explicitly pedagogical framing for its work by offering Zoomcasts, lesson plans, and syllabi. It is a tremendous resource that holds the possibility for moving Victorian studies forward by providing ready-made, high-quality curricular materials that spotlight the voices of writers and thinkers from the Caribbean, Africa, and South Asia in the 19th century. It further emphasizes the importance of bringing insights from a broad range of discourses (e.g., critical race theory, Black studies, postcolonial studies, Native and Indigenous studies, and Latinx studies, to name a few) to studying the work of white British writers of the time period.

Clear and logical navigation offers users multiple points of entry into the materials housed in the project. The Zoomcasts are a series of videos on the methodologies of undisciplining Victorian studies, a unique approach not often seen in pedagogy-based projects. The conversations, particularly Kira Braham, Indu Ohri, Bre Simpson, and Adrian S. Wisnicki's discussions of developing a lesson on Mary Seacole, model how to rethink canonical ways of teaching Victorian studies that center white British writers and thinkers. The discussion about retraining as Victorianists with Alisha Walters and Pearl Chaozon Bauer reminds users that there are broader implications for research as well. The videos could also be used in the classroom to introduce students to theoretical debates in the subfield. Demonstrating the team's commitment to accessibility, the Zoomcasts are closed captioned and provide both transcripts and metadata.

The lesson plans offered on the site are not single lesson plans but clusters of lessons on topics such as "Africa, the Diaspora, and the British Empire." Within the clusters, each lesson takes a distinct angle, modeling the range of disciplinary approaches that can be brought to Victorian studies. These include: "Undisciplining the Victorian Monologue," "Archival Erasure and the Aftermath of Slavery," and "Slavery and Theories of Sexuality, Desire, and Family." Each lesson plan includes a usage guide, goals, primary and secondary source texts to teach, and sample discussion questions. With coverage of both literary and historical sources, the lessons provide compelling examples of the "undisciplining" that the project aims to instigate. Currently, there are two clusters, both focused on African colonies and the African diaspora; the addition of other topics, such as the Raj, would be welcome. The numbering of the collections on the page (numbering a cluster introduction as \#1 and the lesson plans as \#2) is a bit 
confusing; until there are multiple clusters on a single topic, the project team might consider removing the numbering. Further, inclusion of sample assignments on the lesson themes would be a helpful resource for teaching.

The third category of available materials comprises peer-reviewed syllabi, although the word "syllabus" does not do justice to the documents provided. Rather, they include concise, nuanced essays that articulate framing visions for courses like "Victorian Women of the World" and "Unsettling Victorian Literature," along with downloadable syllabi in PDF and Microsoft Word formats. Authors of these syllabi not only discuss what to teach in Victorian studies but how to teach the texts, which is precisely the question that UVC seeks to answer. At first glance, it's not immediately clear that the pages linked in the "Syllabi" section aren't the syllabi themselves but resource pages that include a downloadable syllabus; a small tweak to the overview on the main "Syllabi" page could offer clarity and more direction for users on this point. Moreover, while there is a brief description of the open peer review process on the "About" page, it would be helpful to know what the review criteria for the syllabi are.

In its design and execution, UVC puts the values and practices articulated on its "About" page into practice. The project is an excellent example of giving credit where credit is due, a sign of the care that is central to the team's mission. Furthermore, it has put accessibility at the center of website design. In both form and content, UVC offers a model of pedagogical digital humanities projects that are undisciplining how we teach and contributes to the critical goal of drawing attention to the colonial moorings of white British writing as well as the voices of colonized people in subfields that have, for too long, silenced them.

\section{Footnotes}

1. Notre Dame de Namur University is a private Catholic university in northern California. Kalamazoo College is a private liberal arts college in Michigan. Lehman College, CUNY is a public, Hispanic-serving, urban college in New York City. The University of Nebraska-Lincoln is a public R1 land-grant institution. $\subseteq$

2. Ronjaunee Chatterjee, Alicia Mireles Christoff, and Amy R. Wong, "Undisciplining Victorian Studies," Los Angeles Review of Books, 10 July 2020, https://lareviewofbooks.org/article/undisciplining-victorian-studies.

3. Christina Sharpe, In the Wake: On Blackness and Being (Durham, NC: Duke University Press, 2016). 
4. Bethany Nowviskie, "Capacity through Care," in Debates in the Digital Humanities 2019, eds. Matthew K. Gold and Lauren F. Klein (Minneapolis: University of Minnesota Press, 2019), https://dhdebates.gc.cuny.edu/read/untitled-f2acf72ca469-49d8-be35-67f9ac1e3a60/section/3a53cbc1-5eee-421a-a4f6-82bb5dfb1c17.. 